\title{
INVESTIGATION OF YIELD AND YIELD COMPONENTS OF SUNFLOWER (HelianthuS annuus L.) CULTIVARS IN THE ECOLOGICAL CONDITIONS OF BERLIN (GERMANY)
}

\author{
Canavar, Ö. ${ }^{*}$, Ellmer, F. ${ }^{2}$ and Chmielewski, F.M. ${ }^{3}$ \\ ${ }^{1}$ Adnan Menderes University, Agriculture Faculty, \\ Crop Science Department, Aydin, Turkey \\ ${ }^{2}$ Humboldt University, Agriculture and Horticulture Faculty, \\ Crop Science Department, Berlin, Germany \\ ${ }^{3}$ Humboldt University, Agriculture and Horticulture Faculty, \\ Agroclimatology Department, Berlin, Germany
}

Received: April 10, 2010

Accepted: August 10, 2010

\begin{abstract}
SUMMARY
Sunflower is an important oilseed crop because of its wide adaptability, suitability to mechanization, low labor needs and high protein and oil contents. The present study aimed to investigate the relationship between growing degree days and yield and yield components in different sunflower hybrids and to identify environmental factors and crop characteristics that affect grain yield in sunflower without irrigation in Berlin environmental conditions. The study was conducted in the experiment fields at the Crop Science Department of the Agriculture and Horticulture Faculty of Humboldt University during 2010. The experiment was laid out in a randomized block design, with four blocks of plots of eight Turkish cultivars (Sanbro, Tarsan, DKF-2525, TR-3080, EDR08-01, EDR-08-02, EDR-08-03, EDR-08-04) and two German cultivars (Pegasol, NK Delfi). It was determined that the differences among all the sunflower cultivars were statistically significant for plant height, stem diameter, head diameter, 1000 seed weight, dry matter, harvest index, seed yield per plant, seed yield, leaf number, GDD (Growing Degree Days) and sun radiation. The highest mean stem diameter, harvest index and 1000 seed weight were obtained from Pegasol. NK-Delfi had the highest mean head diameter and consequently the highest seed yield $\left(3,876.6 \mathrm{~kg} \mathrm{ha}^{-1}\right)$, followed by DKF-2525 and Sanbro $\left(3,498.7\right.$ and $3412.9 \mathrm{~kg} \mathrm{ha}^{-1}$, respectively). The sunflower cultivars required between 127 and 137 days, $2,263.57^{\circ} \mathrm{C}$ GDD and $927.54 \mathrm{~h}$ sunshine radiation from planting to maturity, as the mean of all the cultivars. Generally, the seed yields of the Turkish candidate genotypes were lower than those of the other sunflower cultivars. The seed yield of these genotypes can be improved with another agriculture method. The rainfall and cold weather in May slowed the growth of sunflower and also the rainfall and cold weather in August
\end{abstract}

* Corresponding author: Phone: +90256 7727022; Fax: +90256 7727233;

e-mail: ocanvar@adu.edu.tr 
delayed maturity. The dry and hot weather in June and July created stress on plants. In terms of seed yield, NK-Delfi, DKF-2525, Sanbro, and Pegasol proved to be suitable sunflower cultivars to be grown in Berlin. $\begin{array}{ll}\text { Key words: } & \text { sunflower, Helianthus annuus L., yield, GDD, growing degree } \\ \text { days }\end{array}$

\section{INTRODUCTION}

Sunflower is an important oilseed crop because of its high protein and oil contents. Sunflower seeds are used as a source of cooking oil and in confectionary products for human consumption. The oil content of sunflower seed ranges between 36 and 52\%, whereas the protein content is at $28-32 \%$ (Rosa et al., 2009). The seeds contain hulls with high fiber and wax contents and a low protein content, which is considered as a big obstacle for obtaining a better yield of oil and a high-quality protein meal. In order to overcome these constraints, the seeds are dehulled. The annual world sunflower production is around 35.6 million tons with 25.1 million hectares of production area (FAO, 2008). The yield of sunflower in Germany is about $1.96 \mathrm{t} \mathrm{ha}^{-1}$ (FAO, 2008), which is higher than the average yield for the rest of the world ( $\left.1.42 \mathrm{tha}^{-1}\right)$. While Russia is the largest producer of sunflower seed in the world, no single country dominates the production. Although the harvested area of sunflower in India is larger than in other countries, the country's sunflower yields are rather low compared to other countries. The harvested area and production in Germany are lower than in many other countries, but the yield of sunflower in the country is higher than the mean yield on the global scale. Germany is a major buyer of the crop. Russia, Ukraine and Argentina are three of the most important sunflower-producing countries in the world. Environmental factors, especially temperature during the period of seed development and maturation, might have an effect on yield and yield attributes. Sunflower is a temperate zone crop, but it can perform well under a variety of climatic and soil conditions. It can withstand early frost in autumn that usually kills maize and soybean. Having wide adaptability, different sunflower hybrids require different total numbers of cumulative degree-days or growing degree days for growth, development and maturity. All physiological and morphological developments occurring in the plant are markedly influenced by temperature. The flowering and maturity of sunflower is affected by certain climatic conditions. Also, if the relationship between the beginning of the first flowering and maturity is known, the time of harvest can be estimated for healthy crops (Gadir et al., 2007; Önemli, 2005). A wide range of sunflower cultivars are available, each with specific heat unit requirements. Sunflower cultivars range from 1,140 to 1,400 growing degree days using a $7.2^{\circ} \mathrm{C}$ base temperature (Robinson, 1971). The accumulation of GDD determines the maturity of the crop, yield and yield components. However, Sur and Sharma (1999) reported that the total growing degree days decreased from 1,731 to 1,621 with a delay in planting, 
as the late-sown crop experienced lower temperature during the seed filling period. The present study aimed to investigate the relationship between growing degree days and yield and yield components in different sunflower hybrids and to identify environmental factors and crop characteristics that affect grain yield in sunflower without irrigation in the Berlin environment.

\section{MATERIAL AND METHODS}

The field trial was conducted during the 2010 growing season in the experiment station of the Agriculture and Horticulture Faculty of Humboldt University in Berlin, Germany $\left(52^{\circ} 28^{\prime} \mathrm{N} ; 13^{\circ} 18^{\prime} \mathrm{E}\right.$; in the South West Berlin of Germany). The experiment was laid out in a randomized block design with four replicates of plots of eight Turkish cultivars (Sanbro, Tarsan, DKF-2525, TR-3080, EDR-08-01, EDR08-02, EDR-08-03, EDR-08-04) and two German cultivars (Pegasol, NK Delfi), which were evaluated for growth and yield performance in the field. The germination of all sunflower cultivars was analyzed before planting. The meteorological data for the growth period of experimental crop were collected from the Department of Meteorology situated within meteorological stations located less than $200 \mathrm{~m}$ away from the research area on the premises of the Dahlem agriculture experiment area of Humboldt University. The highest temperatures were recorded in late June and July. The temperature decreased suddenly in August, which had a lot of rainy and cold temperature days. The precipitation until May was $6.1 \mathrm{~mm}$ nine days after planting. The precipitation during the growing season was $90.6 \mathrm{~mm}$ in May, 1.6 $\mathrm{mm}$ in June, and $45.5 \mathrm{~mm}$ in July. The total rainfall during the vegetation for sunflower in 2010 was higher than the average annual rainfall in the same period. The soil characteristics of the experimental area are given in Table 1.

Table 1: The soil characteristics of the experimental area.

\begin{tabular}{|c|c|c|c|c|c|c|}
\hline \multirow{2}{*}{ Level (cm) } & \multicolumn{3}{|c|}{ Soil texture (\%) } & \multirow{2}{*}{$\begin{array}{l}\mathrm{pH} \\
(\%)\end{array}$} & \multirow{2}{*}{$\begin{array}{l}\text { Carbon level, } \mathrm{C}_{\mathrm{t}} \\
\quad\left(\mathrm{mg} 100 \mathrm{~g}^{-1}\right)\end{array}$} & \multirow{2}{*}{$\begin{array}{l}\text { Nitrogen level, } N_{t} \\
\quad\left({\left.\mathrm{mg} 100 \mathrm{~g}^{-1}\right)}\right.\end{array}$} \\
\hline & Sand & Silt & Clay & & & \\
\hline $0-30$ & 72.1 & 25.0 & 2.9 & 6.3 & 0.7 & 0.07 \\
\hline
\end{tabular}

According to Table 1, the pH level was normal (6.3\%), the carbon level was low $\left(0.7 \mathrm{mg} 100 \mathrm{~g}^{-1}\right)$, and the nitrogen level was $0.07 \mathrm{mg} 100 \mathrm{~g}^{-1}$. However, the soils of the experimental fields were sandy $(72.1 \%)$ in soil texture. The sunflower cultivars were planted on 22 April. Each plot consisted of four rows $6 \mathrm{~m}$ in length with an inter-row spacing of $75 \mathrm{~cm}$ and intra-row spacing of $25 \mathrm{~cm}$, so the total area of each plot was $16 \mathrm{~m}^{2}$, similarly to Aboudrare et al. (2006). In this study, $60 \mathrm{~kg} \mathrm{~N} \mathrm{ha}^{-1}$ and $60 \mathrm{~kg} \mathrm{~K}_{2} \mathrm{O} \mathrm{ha}{ }^{-1}$ were provided with the application of composted fertilizer (KAS and Kornkali), prior to planting with incorporation into the soil during seedbed preparation. The characters determined were seed yield per decare (SY, unless there was bird damage), plant height, stem diameter (SD), head diameter (HD), seed yield per plant (SYP), 1000 seed weight (TSW), dry weight (DRYM), and harvest index (HI). Weeds were kept under control by hand weeding throughout the crop life cycle. The plant height and leaf number of all sunflowers were determined on 25 randomly 
selected plants from each plot from emergence to maturity. The harvest index (HI) was calculated using the formula:

$\mathrm{HI}=$ economic yield / total biomass $\times 100$.

The harvest index was calculated in agronomy trials as the ratio of seed yield to the aboveground dry matter yield. Ten sunflower cultivars were harvested on 8 September. They were then dried at $30^{\circ} \mathrm{C}$ over four days in a dry machine until $10-12 \%$ seed humidity was reached. A 100 seeds were removed from each head and fresh weights were obtained. Samples were dried in the oven at $40^{\circ} \mathrm{C}$ for at least 48 hours (Cukadar-Olmedo et al., 1997). They were then weighed and moisture data were obtained using the formula:

Seed moisture $(\mathrm{g} / \mathrm{kg})=[($ fresh weight - dry weight $) /$ fresh weight $] \times 1000$

Data was collected on seed yield per unit area (t/ha) according to the following equation:

Seed yield $/\left(\mathrm{t} \mathrm{ha}^{-1}\right)=$ seed weight $(\mathrm{kg} /$ plot $) \times 10,000 \mathrm{~m}^{2} /$ plot area $\left(\mathrm{m}^{2}\right) \times 100$

The yield of seed per plant was determined using the seed from all plots divided by plant number which was numbered in each plot at the harvest. The average daily temperature was used to calculate thermal time (TT) for each day (daily temperature multiplied by the number of days from emergence to physiological maturity). Cardinal temperatures, namely base temperature $\left(T_{\text {base }} 8^{\circ} \mathrm{C}\right)$, optimum temperature $\left(\mathrm{T}_{\mathrm{opt}}\right)$, and maximum temperature $\left(\mathrm{T}_{\max }\right)$ (Chapman et al., 1993; Jones and Kiniry, 1986; Gadir et al., 2007), were assumed in the calculation of heat unit accumulation measured as growing degree days (GDD) using the equation of McMaster and Wilhelm (1997). For the HU equation, $7.2^{\circ} \mathrm{C}$ base temperature for sunflower was chosen as a reasonable compromise among several HU studies; base temperature of $7.2^{\circ} \mathrm{C}$ (Robinson, 1971). Growing degree days and sunshine radiation were calculated at E: emergence, VE: vegetative emergence, R1: bud visible, R3: immature bud, R5.1: first flowering, R5.5: 50\% in flowering, R6: last flowering, R9: physiological maturity stages (Aiken, 2005; Bange, 2000) as:

$\mathrm{GDD}=\left[\left(\mathrm{T}_{\max }+\mathrm{T}_{\min }\right) / 2\right]-\mathrm{T}_{\text {base }}$

(Agele, 2003)

The significance of the main effects and the interactions was determined at the 0.05 and 0.01 probability levels by the F-test. The means of the significant $(P \leq 0.05)$ main effects and interactions were separated using Fisher's Protected LSD Test at $\mathrm{P}=0.05$. The data were statistically analyzed using a standard analysis of variance technique for a randomized design using the TARIST user guide (Açikgöz et al., 1994) and the SSPS and JMP statistical program (SAS Institute Inc. Cary, NC, USA, 2000).

\section{RESULTS AND DISCUSSION}

The data regarding plant height of 10 sunflower hybrids from R1 (bud visible) to R9 (PM, physiological maturity) were significantly different, as shown in Table 2. The hybrid Sanbro produced the maximum $(121.2 \mathrm{~cm})$ plant height, which was higher than the lowest value $(88.2 \mathrm{~cm})$ produced by EDR-08-03 at physiological maturity. 
Table 2: Plant height $(\mathrm{cm})$ of 10 sunflower hybrids from emergence to physiological maturity in Berlin, Germany.

\begin{tabular}{lcccccccc}
\hline CULTIVARS & $\mathrm{E}$ & $\mathrm{VE}$ & $\mathrm{R} 1$ & $\mathrm{R} 3$ & $\mathrm{R} 5.1$ & $\mathrm{R} 5.5$ & $\mathrm{R} 6$ & $\mathrm{R} 9$ \\
\hline Sanbro & 1.4 & 2.4 & 29.4 & 104.6 & 112.5 & 120.2 & 121.3 & 121.2 \\
Tarsan & 1.7 & 2.5 & 30.6 & 94.6 & 98.1 & 99.1 & 99.7 & 99.6 \\
DKF-2525 & 1.5 & 2.5 & 25.9 & 95.6 & 99.6 & 103.3 & 103.9 & 103.8 \\
TR-3080 & 1.6 & 2.5 & 31.8 & 108.4 & 110.0 & 114.0 & 114.8 & 114.6 \\
EDR-08-01 & 1.7 & 2.6 & 34.2 & 93.3 & 93.6 & 95.3 & 95.5 & 95.4 \\
EDR-08-02 & 1.5 & 2.5 & 33.3 & 95.2 & 113.1 & 116.2 & 116.8 & 116.8 \\
EDR-08-03 & 1.7 & 2.5 & 33.3 & 89.8 & 93.1 & 94.9 & 95.0 & 94.9 \\
EDR-08-04 & 1.6 & 2.6 & 21.2 & 79.3 & 83.9 & 88.1 & 88.3 & 88.2 \\
Pegasol & 1.6 & 2.6 & 27.9 & 90.1 & 90.4 & 92.8 & 93.1 & 93.1 \\
NK-Delfi & 1.5 & 2.7 & 33.9 & 98.4 & 113.9 & 119.4 & 120.0 & 120.0 \\
\hline LSD 5\% & $0.222 \mathrm{~ns}$ & $0.248 \mathrm{~ns}$ & $2.812^{\star \star}$ & $4.339^{\star \star}$ & $5.232^{\star \star}$ & $6.035^{\star \star}$ & $6.038^{\star \star}$ & $6.031^{\star \star}$ \\
\hline
\end{tabular}

E: emergence, VE: vegetative emergence,

R1: bud visible, R3: immature bud, R5.1: first flowering,

R5.5: $50 \%$ in flowering, R6: last flowering, R9: physiological maturity

Table 3: Result of analysis of variance for plant height of sunflower.

\begin{tabular}{|c|c|c|c|c|c|c|c|c|c|}
\hline \multirow{2}{*}{ V.S. } & \multirow{2}{*}{ Df } & \multicolumn{8}{|c|}{ Calculated of means square } \\
\hline & & $E$ & VE & R1 & R3 & R5.1 & R5.5 & R6 & R9 \\
\hline Blok & 3 & 0.008 & 0.044 & 18.208 & 13.839 & 52.749 & 34.440 & 37.489 & 37.535 \\
\hline Cultivar & 9 & $0.030 \mathrm{~ns}$ & $0.035 \mathrm{~ns}$ & $69.813^{* \star}$ & $29.050 * *$ & $469.525^{\star *}$ & $579.925^{* *}$ & $606.179 * \star$ & $607.919 * *$ \\
\hline Error & 27 & 0.023 & 0.029 & 3.751 & 8.930 & 12.507 & 17.278 & 17.296 & 17.253 \\
\hline
\end{tabular}

** * Significant at $\mathrm{P} \leq 0.01$ and 0.05 , respectively, ns -non-significant

V.S.: variation source, Df: degree of freedom, E: emergence, VE: vegetative emergence,

R1: bud visible, R3: immature bud, R5.1: first flowering,

R5.5: 50\% in flowering, R6: last flowering, R9: physiological maturity

The plant height of some sunflower cultivars was the lowest or middle group in some stage but could be the highest group at next stages. For example, the Sanbro hybrid was statistically in the third group at the R1 stage but was statistically in the first group at the R5.1, R5.5 and R6 stages. This was due to climate changes like temperature and sun radiation from emergence to physiological maturity during the growth season. The differences in plant height may also be attributed to the genetic potential of hybrids and the other prevailing environmental conditions. The plant height of some sunflower hybrids increased with increasing temperature. Similar results were reported by Anderson et al. (1978) and Gadir (2006).

A separate analysis of variance for sunflower cultivars showed highly significant differences for head diameter (HD), stem diameter (SD), thousand seed weight (TSW), dry matter (DRYM), harvest index (HI), seed yield per plant (SYP) and seed yield (SY), indicating substantial variation among cultivars (Table 4).

The largest head diameter (HD, $16.82 \mathrm{~cm}$ ) was produced by NK-Delfi (Table 4). The head diameters of the EDR-08-01, EDR-08-03, and EDR-08-04 candidate genotypes were lower than those of the other sunflower cultivars, whose head diameter was more than $16 \mathrm{~cm}$. 
Table 4: Head diameter (HD), stem diameter (SD), thousand seed weight (TSW), dry matter (DRYM), harvest index (HI), seed yield per plant (SYP), and seed yield (SY) of 10 sunflower hybrids during physiological maturity in Berlin, Germany.

\begin{tabular}{lccccccc}
\hline \multirow{2}{*}{ CULTIVARS } & HD & SD & TSW & DRYM & HI & SYP & SY \\
\cline { 2 - 7 } & $(\mathrm{cm})$ & $(\mathrm{cm})$ & $(\mathrm{g})$ & $\left(\mathrm{g} \mathrm{plant}^{-1}\right)$ & $(\%)$ & (g plant $\left.^{-1}\right)$ & $\left(\mathrm{kg} \mathrm{ha}^{-1}\right)$ \\
\hline Sanbro & 16.57 & 1.958 & 65.15 & 255.70 & 42.48 & 76.67 & 3412.90 \\
Tarsan & 15.81 & 1.948 & 69.37 & 191.51 & 43.45 & 66.41 & 3218.50 \\
DKF-2525 & 16.20 & 1.870 & 70.27 & 193.13 & 43.87 & 71.87 & 3498.70 \\
TR-3080 & 15.15 & 1.895 & 56.45 & 142.96 & 40.32 & 66.87 & 3295.70 \\
EDR-08-01 & 15.44 & 1.810 & 56.53 & 144.16 & 37.54 & 56.02 & 2700.10 \\
EDR-08-02 & 16.41 & 1.840 & 53.40 & 127.18 & 41.91 & 62.13 & 3078.90 \\
EDR-08-03 & 15.61 & 1.852 & 56.85 & 136.15 & 39.95 & 54.67 & 2658.50 \\
EDR-08-04 & 14.92 & 1.588 & 69.77 & 125.18 & 41.71 & 62.15 & 3028.10 \\
Pegasol & 16.00 & 2.168 & 82.88 & 163.63 & 44.48 & 67.47 & 3244.90 \\
NK-Delfi & 16.82 & 1.863 & 62.90 & 192.76 & 43.99 & 74.89 & 3876.60 \\
\hline LSD 5\% & $1.104^{\star *}$ & $0.144^{* *}$ & $11.239^{\star *}$ & $62.932^{\star *}$ & $2.589^{* *}$ & $7.351^{\star *}$ & $379.385^{\star *}$ \\
\hline
\end{tabular}

Table 5: Result of analysis of variance for head diameter (HD), stem diameter (SD), thousand seed weight (TSW), dry matter (DRYM), harvest index (HI), seed yield per plant (SYP), and seed yield (SY).

\begin{tabular}{lcccccccc}
\hline \multirow{2}{*}{ V.S. } & \multirow{2}{*}{ Df } & \multicolumn{7}{c}{ Calculated of means square } \\
\cline { 3 - 8 } & & HD & SD & TSW & DRYM & HI & SYP & SY \\
\hline Blok & 3 & 0.345 & 0.003 & 62.961 & 293.038 & $10.651^{*}$ & $77.883^{*}$ & 126587.009 \\
Cultivar & 9 & $1.548^{\star}$ & $0.083^{\star *}$ & $326.888^{\star *}$ & $6760.387^{\star *}$ & $19.087^{\star \star}$ & $216.974^{\star *}$ & $529420.367^{\star *}$ \\
Error & 27 & 0.578 & 0.010 & 59.914 & 1878.716 & 3.181 & 25.637 & 68276.854 \\
\hline${ }^{* *}$
\end{tabular}

**, * Significant at $\mathrm{P} \leq 0.01$ and 0.05 , respectively, ns -non-significant

V.S.: variation source, Df: degree of freedom

The result given above shows that the crops which matured in cold temperature and remained in the field for a longer time had higher values of head diameter, while the crops which matured during the very high and cold temperature produced lower values of head diameter. In terms of this property our data showed a parallel with those of Razi and Assad (1999), Goksoy et al. (2002), Sujahta et al. (2002), Seneviratne et al. (2004), Hassan et al. (2005) and Gadir et al. (2006). The maximum stem diameter was obtained from Pegasol $(2.168 \mathrm{~cm})$. The minimum stem diameter $(1.588 \mathrm{~cm})$ was obtained from EDR-08-04. Sanbro, Tarsan, TR3080, DKF-2525 were in the highest group (second and third) with respect to this character after Pegasol. The TSW of the sunflower cultivars ranged from 53.40 to $82.88 \mathrm{~g}$. The Pegasol sunflower cultivar produced the maximum TSW (82.88 g), which was significantly $(\mathrm{p}=0.05)$ different from the other values of this trait. EDR08-02 produced the minimum TSW (53.40 g), as shown in Table 4 . Our data in terms of TSW were similar to those of Razi and Assad (1999), Angadi and Entz (2002), Goksoy et al. (2002), Agele (2003), Gadir (2006), Kaya et al. (2007), Gadir et al. (2007), Tozlu et al. (2008) and Asbag et al. (2009). Tarsan, DKF-2525 and EDR-08-05 were the second highest group with respect to TSW. Westgate (1994) reported that the main reason for grain weight reduction is a decrease in grain filling period due to stress. Our growing period and condition were very long. The rea- 
son for this change of TSW was the genotype-specific influence. Also, environmental conditions had negative or positive effects on the genotypes. Hybrids evaluated in this experiment produced different amounts of dry matter. Sanbro produced the maximum dry matter (255.70 $\left.\mathrm{g}_{\text {plant }}{ }^{-1}\right)$, which was significantly different from DKF-2525 and also on a par with the rest of the genotypes. The TSW data of our sunflower cultivars were higher than the results of Aksyonov (2007), Hassan et al. (2005) and Miralles et al. (1997). Tekelwold et al. (2000) reported that tall plants supporting many leaves could increase total biomass through increased carbon fixation that can ultimately be partitioned. The highest harvest index (44.48\%) was obtained from the Pegasol sunflower cultivar. The lowest harvest index (37.54) was obtained from EDR-08-01, a Turkish candidate sunflower genotype (Table 4). The harvest indexes of all sunflower cultivars were affected by head diameter, leaf number, 1000 seed weight, earliness, lateness, plant height, seed number per head, and sudden variations in environmental conditions. Sanbro was in the highest (first and second) groups with respect to plant height, leaf number and stem diameter. The harvest index of Sanbro was low and the hybrid was in the middle group with respect to this character. The average seed yield per plant of all the sunflower cultivars ranged from $54.67 \mathrm{~g}$ to $76.6 \mathrm{~g}$, averaging $65.91 \mathrm{~g}$ (Table 4). The maximum seed yield per plant (76.67 $\mathrm{g} \mathrm{plant}^{-1}$ ) was observed in Sanbro. The lowest seed yield per plant (54.67 g plant $^{-1}$ ) was found in the EDR-08-03 candidate genotype. The average seed yield of all the sunflower cultivars ranged from 2658.5 to $3876.6 \mathrm{~kg} \mathrm{ha}^{-1}$, with the general average of $3201.3 \mathrm{~kg} \mathrm{ha}^{-1}$ (Table 4). The highest seed yield (3876.6 $\mathrm{kg} \mathrm{ha}^{-1}$ ) was observed in the NK-Delfi sunflower cultivar. The lowest seed yield (2658.5 kg ha-1) was found in EDR-08-03. NK-Delfi and DK-2525 were in the highest group in terms of seed yield, as shown in Table 4. Our data on TSW were similar to those of Agele (2003), Hassan et al. (2005), Saglam and Önemli (2005), Tetik and Turhan (2005), Turhan et al. (2005), Gadir (2006), Krizmanić et al. (2006), Gadir et al. (2007), Škorić et al. (2007), Tozlu et al. (2008), Ahmed and Abdella (2009), Asbag et al. (2009) and Gholinezhad et al. (2009).

Table 6: Leaf number of 10 sunflower hybrids from emergence to physiological maturity in Berlin, Germany.

\begin{tabular}{lcccccccc}
\hline CULTIVARS & $\mathrm{E}$ & $\mathrm{VE}$ & $\mathrm{R} 1$ & $\mathrm{R} 3$ & $\mathrm{R} 5.1$ & $\mathrm{R} 5.5$ & $\mathrm{R} 6$ & $\mathrm{R} 9$ \\
\hline Sanbro & 2.00 & 4.00 & 18.05 & 23.50 & 20.03 & 19.90 & 19.30 & 9.53 \\
Tarsan & 2.00 & 4.00 & 17.68 & 21.78 & 17.25 & 16.65 & 16.30 & 8.00 \\
DKF-2525 & 2.00 & 4.00 & 17.43 & 22.33 & 18.00 & 18.60 & 18.05 & 9.13 \\
TR-3080 & 2.00 & 4.00 & 18.35 & 21.93 & 19.58 & 18.93 & 18.88 & 9.41 \\
EDR-08-01 & 2.00 & 4.00 & 18.10 & 20.00 & 16.45 & 15.78 & 15.22 & 6.01 \\
EDR-08-02 & 2.00 & 4.00 & 20.13 & 22.20 & 18.38 & 16.61 & 16.42 & 7.65 \\
EDR-08-03 & 2.00 & 4.00 & 18.53 & 21.53 & 16.58 & 15.65 & 15.13 & 6.87 \\
EDR-08-04 & 2.00 & 4.00 & 16.13 & 18.43 & 14.15 & 14.05 & 13.35 & 7.30 \\
Pegasol & 2.00 & 4.00 & 18.05 & 20.55 & 17.53 & 17.53 & 15.65 & 8.14 \\
NK-Delfi & 2.00 & 4.00 & 19.4 & 22.63 & 20.28 & 20.28 & 18.00 & 9.97 \\
\hline LSD 5\% & 0.000 & 0.000 & $0.861^{\text {** }}$ & $0.949^{\star *}$ & $1.155^{\star *}$ & $1.267^{\star *}$ & $1.108^{\star *}$ & $0.659^{\star *}$ \\
\hline
\end{tabular}

E: emergence, VE: vegetative emergence,

R1: bud visible, R3: immature bud, R5.1: first flowering,

R5.5: $50 \%$ in flowering, R6: last flowering, R9: physiological maturity 
The highest leaf number (23.5) was obtained from Sanbro at the R3 stage. The lowest leaf number (18.4) was obtained from EDR-08-04 at R3. Even though EDR08-02 had the highest number of leaves at the R1 stage, it was in the middle ranked group at the R3 stage. The difference between the number of leaves of 10 sunflower cultivars was 5, which was statistically significant at the R3 stage, as shown in Table 6. EDR-08-04 was the lowest ranked group in each stage after the VE one. EDR-08-01 and EDR-08-03 were the middle ranked group at the R1 stage, but they were statistically the lowest ranked group at the R3, R5.1, R5.5, R6 and R9 stages.

Sunflower cultivars reached these stages at different times due to different temperature and day length requirements of different genotypes. Floral initiation marks the end of leaf production and the transition from vegetative to reproductive development. It would be expected that by the time of head visible (74 DAS) leaf production would be finished. Instead, it continues further in the four plots, probably because leaves already initiated were still too small to be counted. The first R1 stage was 52 days for EDR-08-03. The last R1 stage occurred after 57.25 days for EDR08-02 and NK-Delfi, as seen in Table 7.

Table 7: Phenological days of 10 sunflower hybrids from emergence to physiological maturity in Berlin, Germany (day).

\begin{tabular}{lcccccccc}
\hline CULTIVARS & $\mathrm{E}$ & $\mathrm{VE}$ & $\mathrm{R} 1$ & $\mathrm{R} 3$ & $\mathrm{R} 5.1$ & $\mathrm{R} 5.5$ & $\mathrm{R} 6$ & $\mathrm{R} 9$ \\
\hline Sanbro & 17.00 & 32.00 & 55.75 & 75.50 & 82.00 & 86.00 & 94.25 & 136.50 \\
Tarsan & 13.00 & 30.00 & 54.25 & 75.50 & 80.25 & 83.25 & 91.00 & 134.50 \\
DKF-2525 & 15.00 & 30.00 & 54.75 & 75.25 & 78.50 & 82.75 & 91.00 & 134.50 \\
TR-3080 & 13.00 & 28.00 & 54.25 & 75.00 & 81.75 & 84.00 & 91.50 & 134.00 \\
EDR-08-01 & 15.00 & 30.00 & 53.00 & 70.00 & 77.00 & 80.50 & 86.75 & 127.00 \\
EDR-08-02 & 13.00 & 28.00 & 57.25 & 76.00 & 85.75 & 92.75 & 102.00 & 136.50 \\
EDR-08-03 & 13.00 & 28.00 & 52.00 & 70.00 & 77.00 & 80.50 & 87.00 & 127.50 \\
EDR-08-04 & 13.00 & 32.00 & 56.00 & 75.50 & 80.25 & 83.00 & 90.00 & 132.25 \\
Pegasol & 13.00 & 30.00 & 54.00 & 75.00 & 78.50 & 81.75 & 88.00 & 134.50 \\
NK-Delfi & 13.00 & 30.00 & 57.25 & 76.50 & 84.25 & 89.00 & 96.25 & 136.50 \\
\hline LSD 5\% & $1.082^{* *}$ & $1.068^{* *}$ & $0.573^{\star *}$ & $0.604^{\star *}$ & $0.764^{* *}$ & $0.723^{* *}$ & $1.322^{* *}$ & $0.683^{* *}$ \\
\hline
\end{tabular}

E: emergence, VE: vegetative emergence,

R1: bud visible, R3: immature bud, R5.1: first flowering,

R5.5: $50 \%$ in flowering, R6: last flowering, R9: physiological maturity

Table 8: Result of analysis of variance for phenological days of sunflower.

\begin{tabular}{lcccccccc}
\hline \multirow{2}{*}{ V.S. } & \multirow{2}{*}{ Df } & \multicolumn{8}{c}{ Calculated of means square } \\
\cline { 2 - 9 } & $\mathrm{E}$ & $\mathrm{VE}$ & $\mathrm{R} 1$ & $\mathrm{R} 3$ & $\mathrm{R} 5.1$ & $\mathrm{R} 5.5$ & $\mathrm{R} 6$ & $\mathrm{R} 9$ \\
\hline Blok & 1.667 & 1.133 & 0.100 & 0.025 & 0.092 & 0.100 & 0.292 & 0.425 \\
Cultivar & $7.822^{\star *}$ & $8.711^{* *}$ & $11.844^{* *}$ & $22.558^{* *}$ & $34.692^{\star *}$ & $60.900^{* *}$ & $87.747^{\star *}$ & $47.014^{* *}$ \\
Error & 0.556 & 0.541 & 0.156 & 0.173 & 0.277 & 0.248 & 0.829 & 0.221 \\
\hline
\end{tabular}

**, * Significant at $\mathrm{P} \leq 0.01$ and 0.05 , respectively, ns -non-significant

V.S.: variation source, Df: degree of freedom, E: emergence, VE: vegetative emergence,

R1: bud visible, R3: immature bud, R5.1: first flowering,

R5.5: $50 \%$ in flowering, R6: last flowering, R9: physiological maturity 
In contrast, EDR-08-02 became the latest hybrid at the R3, R5.1, R5.5, R6 and R9 stages. Pegasol was statistically earlier than NK-Delfi, the other German cultivar. Sanbro was later than all the other sunflower cultivars except EDR-08-02 and NKDelfi in these stages. The PM (R9) of all the cultivars ranged from 127 to 136.5 days (Table 7). Sanbro, NK-Delfi and EDR-08-02 were the latest cultivars with 136 days. EDR-08-01 and EDR-08-03 were earlier than the other genotypes with 127 days. This indicated the least influence of the environment on the characters studied. These results aren't in accordance with the results of Anderson et al. (1978), Unger (1980), Rawson et al. (1984), Miralles et al. (1997), Dwivedi et al. (1998), Kaya et al. (2004), Magaia et al. (2005) and Gadir (2006). Additionally, early hybrids dry faster than later ones, especially in areas with short growing seasons.

Maturity was especially important because of short growing seasons. Therefore, farmers should choose hybrids based on growing season length in their region and their farming system. The use of daily data allows some estimate to be made of the variability in potential yields, which is an important consideration in the establishment of a new crop, especially when farmers are averse to risk. Our results showed that emergence, vegetative stage, bud visible, R3, the first flowering, $50 \%$ days to flowering, the last flowering, and physiological maturity (R9) for the 10 sunflower cultivars were significantly affected by GDD and sunshine duration (Table 9 and Table 10).

Table 9: Result of analysis of variance for GDD of sunflower.

\begin{tabular}{lccccccccc}
\hline \multirow{2}{*}{ V.S. } & \multirow{2}{*}{ Df } & \multicolumn{7}{c}{ Calculated of means square } \\
\cline { 3 - 9 } & & $\mathrm{E}$ & VE & R1 & R3 & R5.1 & R5.5 & R6 & R9 \\
\hline Blok & 3 & 0.005 & 0.034 & 0.029 & 0.009 & 0.115 & 0.217 & 0.082 & 0.009 \\
Cultivar & 9 & $147.103^{* *}$ & $1536.170^{* *}$ & $2944.782^{* *}$ & $9921.142^{* *}$ & $19733.399^{* *}$ & 3536.548 & $2505.394^{* *}$ & $24198.186^{* *}$ \\
Error & 27 & 0.007 & 0.078 & 0.004 & 0.153 & 0.068 & 0.131 & 0.073 & 0.013 \\
\hline
\end{tabular}

** * Significant at $\mathrm{P} \leq 0.01$ and 0.05 , respectively, ns -non-significant

V.S.: variation source, Df: degree of freedom, E: emergence, VE: vegetative emergence,

R1: bud visible, R3: immature bud, R5.1: first flowering,

R5.5: $50 \%$ in flowering, R6: last flowering, R9: physiological maturity

Table 10: Result of analysis of variance for sun radiation of sunflower.

\begin{tabular}{|c|c|c|c|c|c|c|c|c|c|}
\hline \multirow{2}{*}{ V.S. } & \multirow{2}{*}{ Df } & \multicolumn{8}{|c|}{ Calculated of means square } \\
\hline & & $\mathrm{E}$ & VE & R1 & R3 & R5.1 & R5.5 & R6 & R9 \\
\hline Blok & 3 & $0.026 *$ & 0.001 & 0.181 & 0.009 & 0.131 & 0.024 & 0.001 & 0.087 \\
\hline Cultivar & 9 & $178.454^{\star *}$ & $201.920^{* *}$ & $1354.772^{* *}$ & $1380.809^{* *}$ & $2298.498^{\star *}$ & $769.920^{* *}$ & $974.844^{\star *}$ & $2711.808^{\star \star}$ \\
\hline Error & 27 & 0.005 & 0.007 & 0.134 & 0.006 & 0.140 & 0.005 & 0.007 & 0.090 \\
\hline
\end{tabular}

According to Tables 11 and 12 , the sunflower cultivars required $112^{\circ} \mathrm{C}$ (GDD) and $82.73 \mathrm{~h}$ (sun radiation) until emergence, $235.20^{\circ} \mathrm{C}$ (GDD) and $119.80 \mathrm{~h}$ (sun radiation) until vegetative emergence, $608.10^{\circ} \mathrm{C}$ (GDD) and $296.2 \mathrm{~h}$ (sun radiation) until bud visible (R1), $991.31^{\circ} \mathrm{C}(\mathrm{GDD})$ and $506.69 \mathrm{~h}$ (sun radiation) until $\mathrm{R} 3$ stage, $1148.92^{\circ} \mathrm{C}(\mathrm{GDD})$ and $578.19 \mathrm{~h}$ (sun radiation) until the beginning of flowering 


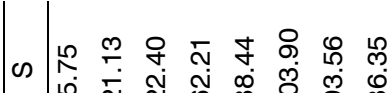
ம

z ஜํํ으 嵌 峁

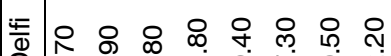

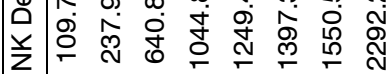

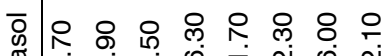
هั

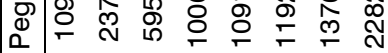

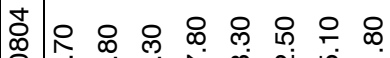
宓 Wิ

ఋ

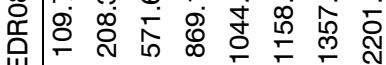

๙ิ๊ ส্ّ के

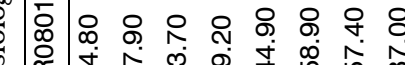

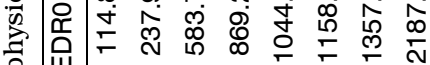
向 은

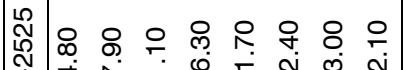

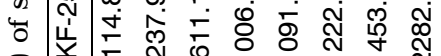
ปิำ

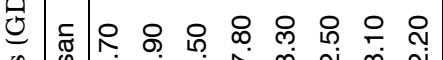

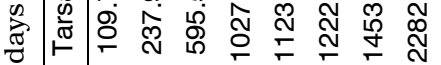

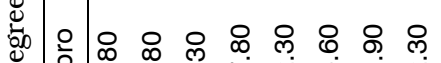
कo

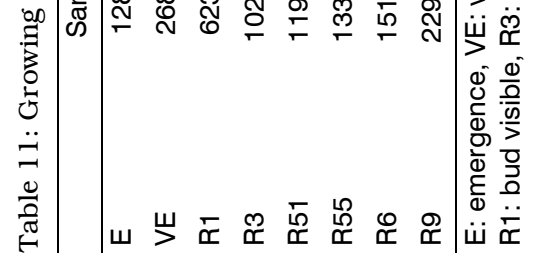

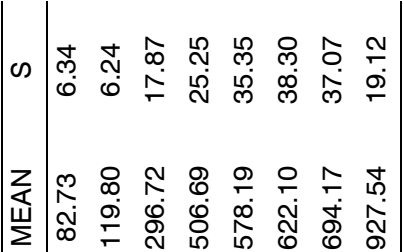

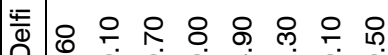
光

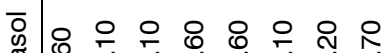

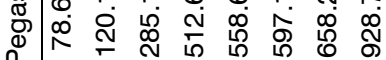

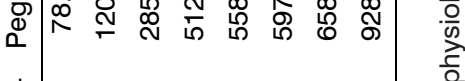

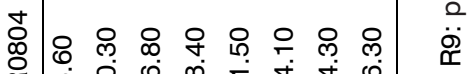

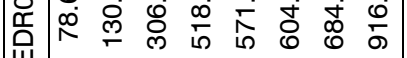
ఇ 穿究 党 융유 웅요용 œ ס

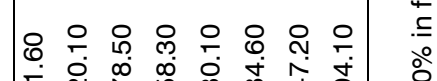

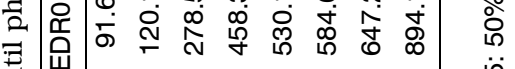
$\Xi$

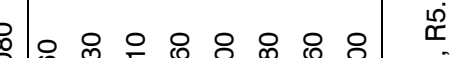

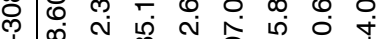
舀 崩 Z 包范 莺 苞

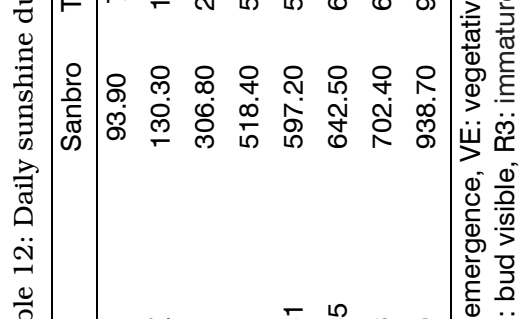
妾| 
(R5.1), $1265.27^{\circ} \mathrm{C}(\mathrm{GDD})$ and $622.10 \mathrm{~h}$ (sun radiation) until the $50 \%$ flowering (R5.5), $1463.39^{\circ} \mathrm{C}$ (GDD) and $693.17 \mathrm{~h}$ (sun radiation) until the last flowering (R6), and between 127 and 137 days, $2263.57^{\circ} \mathrm{C}$ GDD and $927.54 \mathrm{~h}$ sunshine radiation from planting to maturity, as the mean of all sunflower cultivars in Berlin in 2010. The GDD and sun radiation data of all the genotypes in Dahlem were higher than those reported by Angust et al. (1981), Miralles et al. (1997), Nielsen (1999), Sur and Sharma (1999), Ferreira and Abreu (2001) from R5.5 to R9, total GDD, Angandi and Entz (2002), Kaya et al. (2004), Qadir et al. (2007). The hybrids displayed different patterns for days from planting to PM, which was likely due to their different responses to day length, water deficiency and other environmental conditions.

\section{CONCLUSION}

The following results were collected from the experiment. Phenological results of the study showed that because of the long growing period, the grain filling duration prolongation produced seed yields that were above average under Berlin conditions. The hybrids reached 50\% flowering after an average of 80 to 93 days after planting (DAP) and reached PM 127 to 137 DAP. The data obtained in the experiment were higher than those reported in previous studies. Because of the fact that the weather in August was cold, rainy and cloudy, there was a very long time when there were 32-42 days until the R9 stage after R6 stage. The hybrids displayed different patterns for days from planting to PM, which was likely due to their different responses to day length, water deficiency and other environmental conditions. The rainfall and cold weather in May slowed the growth of sunflower and also the rainfall and cold weather in August delayed maturity. The dry and hot weather in June and July created stress on plants. In terms of seed yield, NK-Delfi, DKF-2525, Sanbro, and Pegasol were suitable sunflower cultivars to be grown in Berlin. Also, when new sunflower breeding is to be done for the cold region, seed yield per plant, 1000 seed weight, plant height, GDD, sun radiation, stem diameter, and head diameter should be considered for the newly bred cultivars. Looking at the results of the experiment, it can be concluded that the Northern European latitude has a good potential for sunflower growth.

\section{REFERENCES}

Aboudrare, A., Debaeke, P., Bouaziz, A. and Chekli, H., 2006. Effects of soil tillage and fallow management on soil water storage and sunflower production in a semi-arid Mediterranean climate. Agricultural Water Management 83: 183-196.

Açikgöz, N., Akbaş, M.E., Moghaddam, A. and Özcan, K., 1994. Turkish data based statistics programmer for PC. Turkey Field Crops Congress. Ege University Press. pp. 264-267.

Agele, S.O., 2003. Sunflower responses to weather variations in rainy and dry cropping seasons in a Tropical rainforest zone. IJOP 32: 17-33 
Ahmed, S.B.M and Abdella, A.W.H., 2009. Genetic yield stability in some sunflower (Helianthus annuus L.) hybrids under different environmental conditions of Sudan. Journal of Plant Breeding and Crop Science 1: 016-021.

Aiken, R.M., 2005. Applying Thermal Time Scales to Sunflower Development. Agron. J. 97: 746-754.

Aksyonov, I., 2007. Effect of cultivation measures on index of photosynthesis and yield of sunflower. Helia 30(47): 79-86.

Anderson, W.K., Smith, R.C.G. and McWilliam, J.R., 1978. A Systems approach to the adaptation of sunflower to new environments I. Phenology and development. Field Crops Research 1: 141-152.

Angadi, S.V. and Entz, M.H., 2002. Agronomic performance of different stature sunflower cultivars under different levels of interplant competition. Can. J. Plant Sci. 82: 43-52.

Angus, J.F., Cunningham, R.B., Moncur, M.W. and Mackenzie, D.H., 1981. Phasic development in field crops. I. Thermal response in the seedling phase. Field Crops Res. 3: 365-378.

Asbag, F.T., Gorttapeh, A.H., Moghadam, A.F., Rezaie, M.S., Feghnabi, F., Eizadkhah, M., Jahannavard, S., Parvizi, S. and Pour, S.N.M., 2009. Effects of Planting Date and Irrigation Management on Sunflower Yield and Yield Components. Res. J. Biol. Sci. 4: 306-308.

Bange, M.P., Graeme, L., Hammer, Milroy, S.P., and Rickert, K.G., 2000. Improving Estimates of Individual Leaf Area of Sunflower. Agron. J. 92: 761-765.

Chapmann, S.C., Hanner, G.L. and Meinke, H., 1993. Predicting the leaf area development of sunflower. Field Crops Res. 34: 101-112.

Cukadar-Olmedo, B., Miller, J.F. and Hammond, J.J., 1997. Combining ability of the stay green trait and seed moisture content in sunflower. Crop Sci. 37: 378-382.

FAO, 2008. FAO Statistical Databases. Available online at: http://faostat.fao.org/site/567/DesktopDefault.aspx?PageID $=567$.

Goksoy, A.T., Turkec, A. and Turan, Z.M., 2002. Determination of some agronomic characteristics and hybrid vigor of new improved synthetic varieties in sunflower (Helianthus annuus L.). Helia 25(37): 119-130.

Hassan, F., Cheema, M.A., Gadir, G. and Azim, C.M., 2005. Influence of seasonal variations on yield and yield components of sunflower. Helia 28(43): 145-152.

Dwievedi, R.K., Sangar, B.S., Paliwal, K. and Singil, R.N., 1998. Response of sunflower (Helianthus annuus L.) to date of sowing in northern hills zone of Chattisgarh. MP. Agric. Sic. Dig. 18: 249-251.

Gholinezhad, E., Aynaband, Amir., Ghorthapeh, A.H., Noormohamadi, G., Bernousi, I., 2009. Study of the effect of drought stress on yield. yield components and harvest index of sunflower hybrid iroflor at different levels of nitrogen and plant population. Not. Bot. Hort. Agrobot. Cluj 37(2): 85-94.

Jones, C.A. and Kiniry, J.R. [Eds.], 1986. CERES-Maize: A Simulation Model of Maize Growth and Development. Texas A\&M University Press. College Station TX. pp. 194.

Kaya, Y., Baltensperger, D., Nelson, L. and Miller, J., 2004. Maturity grouping in sunflower (Helianthus annuus L.). Helia 27(40): 257-270.

Krizmanić, M., Mijić, A., Liović, I., Bilandžić, M. and Duvnjak, T., 2006. Sunflower breeding at the agricultural institiute Osijek. Helia 29(44):153-158.

Qadir, G., 2006. Morpho-genetic expression of sunflower under varied temperature and moisture regimes. Ph.D. Thesis, University of Arid Agriculture, Rawalpindi, Pakistan.

Gadir, G., Hassan, F.L. and Malik, M.A., 2007. Growing Degree Days and Yield Relationship in Sunflower (Helianthus annuus L.). Int. J. Agri. Biol. 9(4): 564-568.

Gadir, G., Cheema, M.A., Hassan, F., Ashraf, M., Wahid, M.A., 2007. Relationship of heat units accumulation and fatty acid composition in sunflower. Pak. J. Agri. Sci. 44: 24-29.

McMaster, G.S. and Wilhelm, W.W., 1997. Growing degree days: one equation, two interpretations. Agricultural and Forest Meteorology 87: 291-300.

Magaia, H.E., Freire, M., Monjana, A., Davolio Marani, O., Zazzerini, A., Durante, M., Ecconi, F., 2005. Selection of new sunflower (Helianthus annuus L.) synthetic varieties adapted for production areas of Mozambique. Helia 28(43): 69-76.

Miralles, O.B., Valero, J.A.J., Olalla, F.M.S., 1997. Growth. development and yield of five sunflower hybrids. European Journal of Agronomy 6: 47-59.

Nielsen, D.C., 1999. Water requirements and potential impacts on following crops. In: Meyer, R. et al. [Eds.], High Plains sunflower production handbook. MF-2384, Kansas State Univ. Coop. Ext. Serv., Manhattan. 
Önemli, F., 2005. The Self fertility rates of some hybrid sunflower cultivars. J. Tek. Agri. Fac. 2: 7-12.

Rawson, H.M., Dunstone, R.L., Long, M.J. and Begg, J.E., 1984. Canopy development: Light interception and seed production in sunflower as influenced by temperature and radiation. Aust. J. Plant Physiol. 11: 255-265.

Razi, H. and Assad, M.T., 1999. Comparison of selection criteria in normal and limited irrigation in sunflower. Euphytica 105: 83-90.

Robinson, R.G., 1971. Sunflower phenology: year. variety and date of planting effects on day and growing degree day simulations. Crop Sci. 11: 635-638.

Rosa, P.M., Antoniassi, R., Freitas, S.C., Bizzo, H.R., Zanotto, D.L., Oliveira, M.F., Castiglioni, V.B.R., 2009. Chemical composition of Brazilian sunflower varieties. Helia 32(50): 145156.

SAS Institute, 2000. JMP statistics and graphics guide, Version 4. SAS Institute Inc. Cary, NC, USA. ISBN 1-58025-631-7.

Saglam, C. and Önemli, F., 2005. The effects of sowing date and sowing density on birds damage in the cultivars of sunflower (Helianthus annuus L.). J. Tek. Agri. Fac. 2: 49-56.

Škorić, D., Jocić, S., Hladni, N. and Vannozzi, G.P., 2007. An analysis of heterotic potential for agronomically important traits in sunflower (Helianthus annuus L.). Helia 30(46): 55-74.

Škorić, D., 2009. Sunflower breeding for resistance to abiotic stresses. Helia 32(50): 1-16.

Sur, H.S. and Sharma, A.R., 1999. Response to sowing dates and performance of different sunflower hybrids during rainy season in high intensity cropping systems. Indian J. Agri. Sci. 69: 683-689.

Unger, P.W., 1980. Planting date effects on growth, yield, and oil of irrigated sunflower. Agronomy Journal 72: 914-916.

Tekelwold, A., Jayarmaiah, H. and Jagadesh, B.N., 2000. Correlation and path analysis of physiomorphological characters of sunflower (Helianthus annuus L.) as related to breeding method. Helia 23(32): 105-114.

Tetik, Ü and Turhan, H., 2005. The effect of planting of planting date on plant growth and seed yield in sunflower. Türkiye VI Tarla Bitkileri Kongresi, 5-9 Eylül 2005. Antalya (Presented) Cilt I: 7-10.

Tozlu, E., Dizikisa, T., Kumlay, A.M., Okcu, M., Pehluvan, M. and Kaya, C., 2008. ErzurumPasinler Ekolojik Koşullarinda Yetiştirilen Bazi Yaglik Ayçiçegi (Helianthus annuus L.) Hibridlerinin Agronomik Performanslarinin Belirlenmesi. Tarim Bilimleri Dergisi 14: 359-364. 
